\title{
PENERAPAN METODE BERMAIN PERAN UNTUK MENINGKATKAN KETERAMPILAN BERBICARA MENGGUNAKAN BAHASA BALI
}

\author{
Ni Nyoman Perni \\ SMPN 6 Singaraja \\ email : nymnperni@gmail.com
}

\begin{abstract}
ABSTRAK
Tujuan utama dari penelitian adalah untuk meningkatkan keterampilan berbicara menggunakan Bahasa Bali pada Siswa Kelas IX B2 SMP Negeri 6 Singaraja Semester Genap Tahun Pelajaran 2018/2019 melalui Penerapan Metode Bermain Peran. Penelitian ini merupakan penelitian tindakan kelas yang terdiri dari dua siklus. Setiap siklus terdiri dari 4 tahapan, yaitu: perencanaan, pelaksanaan tindakan, observasi/evaluasi, dan refleksi. Subjek penelitian ini adalah siswa kelas IX B2 SMP Negeri 6 Singaraja semester genap tahun pelajaran 2018/2019 sebanyak 31 orang siswa. Data tentang keterampilan siswa dalam berbicara menggunakan Bahasa Bali dikumpulkan melalui tes keterampilan berbicara. Selanjutnya data yang dikumpulkan ini dianalisis secara dekriptif. Hasil penelitian menunjukkan bahwa, penerapan Metode Bermain Peran dalam pembelajaran Bahasa Bali dapat meningkatkan keterampilan siswa dalam berbicara menggunakan Bahasa Bali, yaitu dari rata-rata nilai 77 (baik) pada siklus I menjadi 82 (sangat baik) pada siklus II.
\end{abstract}

Kata kunci: Bermain Peran, Berbicara Bahasa Bali.

\begin{abstract}
The main objective of the study was to improve speaking skills using Balinese in Class IX B2 Singaraja State Middle 6 Even Semester 2018/2019 Academic Year through the Application of Role Playing Methods. This research is a classroom action research consisting of two cycles. Each cycle consists of 4 stages, namely: planning, action, observation / evaluation, and reflection. The subjects of this study were class IX B2 Singaraja Public Middle School 6 even semester 2018/2019 school year as many as 31 students. Data on students' skills in speaking in Balinese is collected through speaking skills tests. Furthermore, the data collected is analyzed descriptively. The results showed that the application of the Play Method The role in learning Balinese could improve students' skills in speaking in Balinese, that is, from an average of 77 (good) in the first cycle to 82 (very good) in the second cycle..
\end{abstract}

Keywords: Role Playing, Speaking Balinese 


\section{Pendahuluan}

Dimasukkannya Bahasa Bali dalam kurikulum sekolah di Bali merupakan satu upaya untuk melestarikan Bahasa Bali yang semakin jarang penggunaannya, baik dalam lingkungan keluarga, sekolah, maupun masyarakat. Pembelajaran Bahasa Bali di sekolah diharapkan dapat meningkatkan pengetahuan dan keterampilan siswa dalam memahami dan menggunakan bahasa Bali baik di lingkungan sekolah maupun di masyarakat serta dapat menunjang pelestarian Bahasa Bali. Terkait dengan hal ini, pada tanggal 26 September Gubernur Provinsi Bali menerbitkan Peraturan Nomor 80 tentang Pelindungan dan penggunaan Bahasa, Sastra, dan Aksara Bali seta Penyelenggaraan Bulan Bahasa.

Pelajaran Bahasa Bali di sekolah, khususnya di Bali memiliki status sebagai muatan lokal wajib. Hal ini menunjukkan bahwa pelajaran Bahasa Bali memang benar-benar harus di kuasai oleh para siswa. Berdasarkan Kurikulum Tingkat Satuan Pendidik (KTSP), materi dalam pelajaran bahasa Bali sangat padat kompleks, sedangkan pelajaran untuk SMP hanya 2 jam pelajaran per minggu. Kondisi ini merupakan satu kendala dalam pencapaian tujuan pembelajaran Bahasa Bali secara tuntas. Berdasarkan pengamatan dan pengalaman peneliti yang juga merupakan guru mata pelajaran Bahasa Bali di SMP Negeri 6 Singaraja, bahwa hasil belajar Bahasa Bali siswa SMP Negeri 6 Singaraja masih rendah, terutama untuk Standar Kompetensi (SK) Berbicara atau berkominkasi menggunakan Bahasa Bali.

Kemampuan berbicara merupakan salah satu kemampuan berbahasa yang perlu dimiliki oleh seseorang, terlebih lagi siswa. Demikian juga halnya dalam Bahasa Bali, kemampuan ini wajib dimiliki oleh setiap siswa, karena digunakan dalam proses pembelajaran, seperti: mengemukakan pendapat, bertanya, menjawab pertanyaan, atau berargumentasi dalam diskusi. Kemampuan ini bukanlah kemampuan yang diwariskan secara turun tumurun, walau pada dasarnya secara alamiah manusia dapat berbicara. Namun untuk dapat berbicara yang baik dan benar mereka perlu latihan dan bimbingan, serta latihan ini secara alami dimulai dari lingkungan keluarga. Latihan dan bimbingan intensif secara formal dilakukan di sekolah oleh guru, khususnya guru bahasa. Pada umumnya dalam berkomunikasi, seseorang lebih banyak melakukan komunikasi secara lisan dibandingkan dengan cara lain, hal ini dikemukakan oleh Rankin (dalam Wendra, 2005) yang telah melakukan survey terhadap 68 orang dari berbagai pekerjaan dan jabatan selama dua bulan. Hasil survey menunjukkan bahwa mereka menggunakan waktu berkomunikasi melalui: (1) menyimak 45\%, (2) berbicara $30 \%$, (3) membaca $16 \%$, dan (4) menulis $9 \%$. Temuan ini menunjukkan bahwa kegiatan berbicara menyita waktu $30 \%$ semua kegiatan bahasa kita yang merupakan persentase yang cukup besar, yaitu berada di urutan kedua setelah menyimak.

Arsjad (1998) menyatakan bahwa, "keterampilan dalam berbahasa terdiri atas empat aspek, yaitu keterampilan dalam: menyimak, berbicara, membaca, dan menulis. Keempat aspek tersebut merupakan satu kesatuan yang utuh. Seluruh keterampilan berbahasa tersebut berkaitan saling mendukung dalam penyelenggaraan proses pembelajaran. Misalnya: saat siswa diminta oleh guru mengemukakan pendapat secara lisan, saat diskusi kelompok dalam memecahkan masalah yang berhubungan dengan satu topik yang sedang diibahas. Kemampuan berbicara dalam mengemukakan pendapat merupakan hal penting yang harus dimiliki oleh siswa (Widianti, 2015). Kemampuan untuk mengungkapkan pendapat ini sangat penting bagi siswa dalam hal mengemukakan sanggahan, persetujuan, dan penolakan yang disampaikan melalui bahasa lisan. Kemampuan ini sangat diperlukan oleh siswa saat berinteraksi di lingkungan sekolah maupun di masyarakat. Di lingkungan sekolah, keterampilan mengumukakan pendapat diperlukan saat berdiskusi di dalam kelas, rapat OSIS, lomba debat, dan sebagainya. Berbicara dalam situasi formal sering timbul rasa gugup, sehingga gagasan yang dikemukakan menjadi tidak teratur dan akhirnya bahasa yang digunakan tidak teratur, bahkan ada yang tidak berani berbicara. Anggapan seseorang bahwa seorang pelajar telah mampu berbicara lebih baik dari pada orang yang pendidikanya kurang telah menyebabkan pembelajaran kemampuan berbicara atau berargumentasi ini sedikit diabaikan. Anggapan ini juga terjadi pada pelajaran bahasa daerah Bali pada sekolah di Bali, bahwa siswa dianggap 
sudah mampu berbicara dengan bahasa Bali, karena bahasa Bali merupakan bahasa lbu bagi masyarakat Bali. Antara (2008) menyatakan bahwa, berbicara dalam situasi yang formal dengan menggunakan bahasa Bali yang baik dan benar sesuai dengan anggah ungguhing basa atau sor singgih basa memerlukan latihan dan bimbingan yang intensif.

Pembelajaran Bahasa Bali di sekolah menuntut siswa untuk dapat berbicara secara lisan melalui bertanya dan menjawab pertanyaan dalam proses pembelajaran, menyampaikan pendapat dalam diskusi pemecahan masalah yang diberikan oleh guru. Dalam hal ini peranan diskusi sangat dominan dalam pelajaran berbicara bahasa Bali yang baik dan benar, seperti bagaimana menggunakan dengan tepat anggah ungguhing basa ketika berbicara dengan sesama teman, dan bagaimana berbicara dengan guru. Berbicara adalah suatu keterampilan berbahasa yang berkembang pada kehidupan anak yang didahului oleh keterampilan menyimak, pada masa tersebutlah kemampuan berbicar atau berujar dipelajari. Berbicara sudah barang tentu erat berhubungan dengan perkembangan kosa kata yang diperoleh anak melalui kegiatan menyimak dan membaca (Siska, 2011). Berbicara secara umum dapat diartikan sebagai suatu penyampaian ide atau gagasan, pikiran kepada orang lain dengan menggunakan bahasa lisan sehingga maksud tersebut dapat dipahami orang lain (Kusmintayu, 2012). Sebelum matang dalam perkembangan bahasa juga merupakan suatu keterlambatan dalam kegiatan berbahasa. Asjad dan Mukti (1993) menyatakan bahwa, argumen yang kuat harus ditunjang pemakaian bahasa yang baik dan benar. Cara berbicara juga harus sistimatis agar imformasi yang disampaikan efektif (Sunarsih, 2012).

Keterampilan seseorang dalam berbicara atau berkomunikasi di masyarakat menunjukkan kematangan atau kedewasaan pribadinya. Menurut Wendra (2005), terdapat empat keterampilan utama yang merupakan ciri pribadi yang dewasa (mature personality) yaitu: (1) Keterampilan sosial (social skill) adalah kemampuan untuk berpatisipasi secara efektif dalam hubungan masyarakat, (2) Keterampilan semantik (semantic skill) adalah kemampuan untuk memilih dan menggunakan kata-kata dengan tepat dan penuh pengertian, (3) Keterampilan fonetik (phonetic skill) adalah kemampuan unsur-unsur fonetik bahasa yang digunakan secara tepat, (4) Keterampilan Vokal (vocal skill) adalah kemampuan untuk menciptakan efek emosional yang diinginkan dengan suara yang digunakan.

Menilai keterampilan berbicara siswa bukanlah hal yang mudah untuk dilakukan. Lee (dalam Saddhono dan Slamet, 2012) mengungkapkan bahwa alat penilaian (tes) itu harus dapat menilai kemampuan mengkomunikasikan gagasan yang tentu saja mencakup kemampuan menggunakan kata, kalimat, dan wacana yang sekaligus mencakup kemampuan kognitif dan psikomotorik. Menurut Nurgiyantoro (1995), aspek yang digunakan dalam menilai keterampilan berbicara meliputi: (1) keakuratan informasi, (2) hubungan antar informasi, (3) ketepatan struktur dan kosa kata, (4) kelancaran, (5) kewajaran, dan (6) gaya pengucapan. Sedangkan Rofi"uddin dan Zuhdi (2001/2002) menyebutkan bahwa aspek-aspek yang dinilai dalam penilaian keterampilan berbicara secara umum dibedakan menjadi dua, yaitu: (1) aspek kebahasaan yang meliputi: a) tekanan, b) ucapan, c) nada dan irama, d) persendian, e) kosa kata/ungkapan atau diksi, dan f) struktur kalimat yang digunakan, (2) aspek nonkebahasaan yang meliputi: a) kelancaran, b) pengungkapan materi wicara, c) keberanian, d) keramahan, d) ketertiban, f) semangat, g) sikap, dan h) perhatian. Selanjutnya Rofi"uddin dan Zuhdi (2002) menyebutkan bahwa penilaian dalam keterampilan berbicara didukung dengan pengamatan (observasi) terhadap siswa yang meliputi aspek-aspek: (1) pemerataan kesempatan berbicara, (2) keterarahan pembicaraan, (3) kejelasan bahasa yang digunakan, (4) kebakuan bahasa yang digunakan, (5) penalaran dalam berbicara, (6) kemampuan mengemukakan ide baru, (7) kemampuan menarik kesimpulan, (8) kesopanan dan saling menghargai, (9) keterkendalian proses berbicara, (10) ketertiban berbicara, (11) kehangatan dan kegairahan dalam berbicara, dan (12) pengendalian emosi.

Dalam penelitian ini, aspek-aspek yang dinilai dalam penilaian keterampilan siswa dalam berbicara Bahasa Bali dilakukan dengan memodifikasi pendapat para ahli di atas, yakni: (1) pilihan kata, (2) pelafalan, (3) intonasi, (4) kelancaran, pemahaman isi. 
Bedasarkan pengamatan dan pengalaman peneliti yang juga merupakan guru mata pelajaran Bahasa Bali di SMP Negeri 6 Singaraja, bahwa siswa masih kurang terampil serta masih merasa malu untuk mengemukakan pendapat. Sebenarnya, keterampilan mengemukakan pendapat sudah diajarkan sejak mereka masuk Sekolah Dasar (SD), namun hasil yang diperoleh masih kurang memuaskan. Dewasa ini, rendahnya keterampilan mengemukakan pendapat siswa masih sering dikeluhkan oleh sebagian besar guru. Untuk mata pelajaran Bahasa Bali, hal ini juga ditemukan pada siswa kelas IX SMP Negeri 6 Singaraja, khususnya Kelas IX B2. Setiap kali guru mata pelajaran memberikan masalah yang menuntut mereka untuk berbicara atau menyampaikan pendapat, mereka tidak mau bahkan tidak ada yang berani untuk mengemukakan pendapatnya. Jika ini terjadi secara berkesinambungan, maka tujuan pembelajaran, khususnya untuk Standar Kompetensi berbicara tidak akan tercapai.

Rendahnya pencapaian hasil belajar untuk standar kompetensi dalam berbicara pada pelajaran bahasa Bali khususnya siswa kelas IX B2 SMP Negeri 6 Singaraja terjadi karena siswa masih malu, takut yang berlebihan karena siswa merasa tidak mampu atau tidak bisa berbicara dengan bahasa Bali, apa lagi dengan kaidah-kaidah berbicara atau aras tutur, yang dalam hal ini dikenal dengan Sor Singgih Basa. Selama ini peneliti sekaligus guru mata pelajaran Bahasa Bali belum pernah memanfaatkan salah satu pembelajaran khusus untuk belajar berbicara dalam bahasa Bali.

Berdasarkan uraian di atas dipandang perlu diadakan tindakan untuk mengatasi masalah tersebut. Sebuah tindakan yang menciptakan suasana menyenangkan dalam belajar, sehingga rasa malu siswa akan berkurang serta meningkatnya keaktifan siswa dalam proses pembelajaran. Jika siswa sudah senang dan aktif dalam pembelajaran, dapat dipastikan hasil belajar akan menjadi lebih baik. Terkait dengan ini salah satu metode pembelajaran yang diyakini dapat memecahkan masalah ini adalah Metode Bermain Peran. Atas dasar keyakinan ini pula peneliti akan melaksanakan penelitian tindakan kelas dengan judul: "Penerapan Metode Bermain Peran untuk Meningkatkan Keterampilan Berbicara Menggunakan Bahasa Bali pada Siswa Kelas IX B2 SMP Negeri 6 Singaraja Semester Genap Tahun Pelajaran 2018/2019"

Sejalan dengan sejumlah permasalahan dalam pembelajaran Bahasa Bali, khususnya dalam berbicara menggunakan Bahasa Bali yang terdapat di SMP Negeri 6 Singaraja sebagaimana telah dikemukakan di atas, secara eksplisit rumusan permasalahan penelitian tindakan ini adalah apakah penerapan Metode Bermain Peran dapat meningkatkan keterampilan berbicara menggunakan Bahasa Bali pada Siswa Kelas IX B2 SMP Negeri 6 Singaraja Semester Genap Tahun Pelajaran 2018/2019?.

Terkait dengan permasalahan di atas, tujuan penelitian ini adalah untuk meningkatkan keterampilan berbicara menggunakan Bahasa Bali pada Siswa Kelas IX B2 SMP Negeri 6 Singaraja Semester Genap Tahun Pelajaran 2018/2019 melalui Penerapan Metode Bermain Peran.

\section{Metode}

Penelitian yang dilaksanakan ini merupakan penelitian tindakan kelas, yang dilaksanakan dalam dua siklus, dengan masing-masing siklus terdiri atas 4 tahapan yaitu: perencanaan tindakan, pelaksanaan tindakan, observasi dan evaluasi, serta refleksi.

Penelitian tindakan kelas ini dilakukan di SMP Negeri 6 Singaraja, dengan waktu pelaksanaannya pada Semester Genap tahun pelajaran 2018/2019 mulai bulan Januari sampai dengan Bulan April 2019 dengan subjek dari penelitian adalah siswa kelas IX B2 yang terdiri atas 31 orang siswa.

Data keterampilan siswa dalam dalam berbicara menggunakan Bahasa Bali dikumpulkan melalui tes keterampilan berbicara melalaui bermain peran. Instrumen yang digunakan untuk menilai keterampilan berbicara menggunakan Bahasa Bali adalah lembar pengamatan yang memuat aspek-aspek: (1) Pilihan Kata, (2) Pelafalan, (3) Intonasi, (4) Kelancaran, (5), Ekspresi, 
(6) Pemahaman Isi. Rentangan skor untuk masing-masing aspek adalah 1 sampai dengan 5 (skala Likert).

Data tentang keterampilan siswa dalam berbicara menggunakan Bahasa Bali dianalisis secara deskriptif. Menginat rentangan skor untuk masing-masing aspek adalah 1 sampai dengan 5, maka skor maksimun masing-masing aspek adalah 5 dan skor minimumnya adalah 1. Karena yang dinilai ada 6 aspek, maka total skor maksimal yang mungkin dicapai oleh siswa adalah 30 dan minimalnya adalah 6 . Selanjutnya untuk menghitung nilai yang diperoleh masing-masing siswa, total skornya dikonversi ke dalam skala 100. Selanjutnya Rata-rata kelas ( ) dari nilai keterampilan siswa dalam Bali dikatagorikan lima, yaitu: sangat baik, baik, cukup baik, kurang baik, dan sangat kurang baik. Untuk mengetahui ada atau tidaknya peningkatan keterampilan siswa dalam berbicara menggunakan Bahasa Bali, rata-rata skor pada siklus I dibandingkan dengan rata-rata skor pada siklus II. Indikator untuk menyatakan terampil atau kurang terampilnya siswa dalam berbicara menggunakan Bahasa Bali ditentukan oleh Ketuntasan Belajar Klasikal (KK) yang dicapai siswa. Kriteria keberhasilan untuk masingmasing siklus adalah $\mathrm{KK}$ minimal 78.

Secara eksplisit indikator keberhasilan dari penelitian ini adalah: (1) rata-rata nilai keterampilan siswa dalam berbicara menggunakan Bahasa Bali meningkat dari siklus I ke siklus II, dan (2) Ketuntasan Belajar Klasikal (KK) lebih besar dari 78.

\section{Hasil Dan Pembahasan}

Berdasarkan analisis data pada siklus I, maka didapat rata-rata nilai keterampilan berbicara menggunakan Bahasa Bali pada siklus I sebesar 77 yang secara kualitatif tergolong baik, ketuntasan belajar klasikal sebesar $65 \%$. Menurut kreteria keberhasilan per siklus yang ditetapkan, maka keterampilan berbicara menggunakan Bahasa Bali dikatakan tercapai apabila ketuntasan belajar klasikal keterampilan siswa dalam berbicara menggunakan Bahasa Bali minimal $78 \%$. Mengingat ketuntasan belajar siswa keterampilan berbicara menggunakan Bahasa Bali sebesar $65 \%$ pada siklus I, maka tindakan pada siklus I belum memenuhi kreteria yang ditetapkan.

Bertolak dari kekurangan-kekekurangan yang terdapat pada silkus I. Peneliti melakukan perbaikan tindakan untuk selanjutnya diterapkan pada siklus II. Perbaikan tindakan yang dimaksud adalah sebagai berikut.

a. Untuk menghindari banyaknya pertanyaan siswa yang terlibat dalam pemeranan, guru menugaskan sebagai tugas rumah agar masing-masing anggota kelompok untuk mempelajari naskah drama, memahami, dan menghayati tokoh yang akan diperankan masing-masing dengan baik, dengan harapan jalannya pementasan sesuai dengan skenario dan alokasi waktu yang telah ditetapkan.

b. Untuk membuat pemeran yang tampil sesuai dengan skenario, guru memberi kesempatan kepada pemeran untuk bertanya di luar waktu/jam pentas, dan pertanyaan ini dapat disamapaikan melalui sms, wa, atau facebook.

c. Untuk membuat kesimpulan yang tepat, guru menegaskan kembali agar siswa mempelajari dengan baik naskah yang dibuat, memahami dan mehayati peran yang dimainkan.

d. Untuk menghindari tidak terjadinya kelebihan waktu yang digunakan dalam pementasan, guru menekankan agar masing-masing pemeran betul-betul tampil sesuai dengan skenario yang telah dipelajari, khususnya alokasi waktu yang disediakan.

Selain kekurangan-kekurangan yang terjadi pada siklus I terdapat keunggulan yang sebaiknya tetap dipertahankan untuk pelaksanaan tindakan siklus berikutnya, yaitu siswa sudah terlihat antusias dan aktif dalam mengikuti pembelajaran yang diterapkan guru. Hal ini tercermin dari respon mereka terhadap petunjuk dan arahan guru, siswa aktif bertanya kepada guru mengenai hal-hal yang belum dipahami dan telah berani menyampaikan ide atau pendapatnya.

Berdasarkan penerapan rancangan pada siklus II yang merupakan perbaikan pada siklus I, ternyata terjadi peningkatan yang cukup signifikan terhadap keterampilan siswa dalam berbicara menggunakan Bahasa Bali. Hal ini ditunjukkan dengan rata-rata nilai keterampilan 
siswa dalam berbicara menggunakan Bahasa Bali meningkat dari 77 menjadi 82, serta KK meningkat dari $65 \%$ menjadi $84 \%$. Secara kualitatif rata-rata nilai keterampilan siswa dalam berbicara menggunakan Bahasa Bali dari siklus I ke siklus II juga mengalami peningkatan yaitu dari kategori "baik" menjadi "sangat baik".

Sesuai dengan hasil refleksi terhadap pelaksanaan tindakan pada siklus II, peneliti kembali mengkaji kekurangan-kekurangan terkait dengan pelaksanaan tindakan yang telah dilaksanakan. Hal ini dimaksudkan untuk merumuskan rekomendasi dari penelitian tindakan kelas ini. Dari hasil observasi tindakan yang dilakukan pada siklus II masih terdapat beberapa kekurangan, yakni sebagai berikut.

Masih ada kelomppok yang kekurangan waktu untuk berdiskusi, sehingga mereka kurang memperhatikan kelompok lain yang sedang pentas.

Masih terdapat Siswa mengalami kesulitan dalam memahami makna yang terkandung dalam drama yang dipentaskan.

Selain kekurangan-kekurangan yang terjadi pada siklus II terdapat suatu kelebihan yang sebaiknya tetap dipertahankan untuk pelaksanaan pembelajaran berikutnya, yaitu siswa sudah terlihat antusias dan aktif dalam mengemukakan gagasan dalam diskusi maupun pada saat pentas. Secara umum pembelajaran Bahasa Bali dengan metode bermain peran sudah berlangsung dengan baik.

Beberapa temuan penelitian mengenai penerapan Metode Bermain Peran untuk meningkatkan keterampilan siswa dalam berbicara menggunakan Bahasa Bali dapat juga dilihat pada beberapa hasil penelitian, diantaranya: (1) hasil Penelitian berjudul "Penerapan Metode Bermain Peran untuk Meningkatkan Kemampuan Berbicara Sor Singgih Bahasa Bali Siswa" yang dilakukan oleh Suwandewi (2013), menyatakan bahwa penerapan Metode Bermain Peran dapat meningkatkan kemampuan siswa dalam Berbicara Sor Singgih Bahasa Bali, (2) hasil penelitian yang dilakukan oleh Wiastra (2013) yang berjudul "Penerapan Metode Bermain Peran Untuk Meningkatkan Kemampuan Berbicara Siswa Kelas IX.3 SMP Negeri 2 Denpasar Tahun 2012/2013", menunjukkan bahwa penerapan Metode Bermain Peran dapat meningkatkan kemampuan berbicara siswa, dan (3) temuan penelitian yang dilakukan oleh Sunarto (2010) dengan judul "Penerapan Metode Bermain Peran untuk Meningkatkan Kemampuan Berbicara Siswa", menunjukkan bahwa penerapan Metode Bermain Peran dapat meningkatkan keterampilan berbicara siswa.

Terdapat beberapa keunggulan dari metode Bermain Peran yang diterapkan dalam pembelajaran antara lain: (1) sangat cocok diterapkan untuk kelas besar (lebih dari 30 orang), (2) sangat cocok diterapkan pada kelas yang heterogen baik dari sisi akademik maupun nonakademik. Karena dalam suatu permainan drama, satu kelompok terdiri atas anggota-anggota yang hetorogen, dan melalui keheterogenan ini mereka akan dapat saling mamahami, saling membantu, serta sangat memungkinkan untuk tumbuh dan berkembangnya soft skill masingmasing siswa, dan (3) setiap siswa mempunyai kesempatan untuk menunjukkan deksistensi dirinya, baik secara akademik maupun non-akademik.

Mengacu pada paparan di atas, penelitian tindakan kelas ini secara umum dapat dikatakan berhasil karena telah memenuhi indikator-indikator keberhasilan yang telah ditetapkan, yaitu: (1) terjadi peningkatan keterampilan siswa dalam berbicara menggunakan Bahasa Bali dari siklus I ke siklus II, (2) terjadi peningkatan ketuntasan belajar klasikal (KK) dari siklus I ke siklus II, (3) Rata-rata kelas nilai keterampilan siswa dalam berbicara menggunakan Bahasa Bali setelah pelaksanaan siklus II sebesar 82 yang tergolong sangat baik, dan (4) ketuntasan belajar pada akhir siklus II adalah $84 \%$..

\section{Simpulan dan Saran}

Berdasarkan hasil penelitian dan pembahasan yang telah dipaparkan sebelumnya dapat disimpulkan bahwa penerapan Metode Bermain Peran mampu meningkatkan keterampilan berbicara menggunakan Bahasa Bali pada siswa kelas IX B2 SMP Negeri 6 Singaraja semester Genap tahun pelajaran 2018/2019. Pada siklus I rata-rata nilai keteramppilan siswa 
dalam berbicara menggunakan Bahasa Bali sebesar 77 yang secara kualitas tergolong baik, meningkat menjadi 82 yang secara kualitas tergolong sangat baik pada siklus II. Demikian juga dengan ketuntasan belajar klasikal sebesar $65 \%$ pada siklus I meningkat menjadi $84 \%$ pada siklus II.

Mengacu pada simpulan dari penelitian tindakan kelas ini, dapat dikemukakan saransaran: (1) diharapkan kepada guru kelas IX B2 SMP Negeri 6 Singaraja untuk tetap menerapkan Metode Bermain Peran walaupun penelitian ini telah berakhir, karena ini telah terbukti mampu mengatasi masalah rendahnya keterampilan siswa dalam berbicara menggunakan Bahasa Bali, dan (2) kepada pembaca yang berminat diharapkan untuk mengadakan penelitian lebih lanjut mengenai penerapan Metode Bermain Peran pada mata pelajaran lainnya yang sesuai dalam rangka lebih mengefektifkan pembelajaran dan melatih kerjasama siswa dalam berdiskusi, sehingga pembelajaran menjadi lebih hidup. Sudah tentu dalam mengimplementasikan metode ini perlu memperhatikan segala kendala-kendala yang peneliti alami.

\section{Daftar Rujukan}

Antara. 1994. Kesusastraan Bali Purwa. Singaraja: STKIP Singaraja.

Arsjad, Maidar G., Mukti US. 1998. Pembinaan Kemampuan Berbicara Bahasa Indonesia. Jakarta: Bumi Aksara.

Baroroh, K., 2011. Upaya meningkatkan nilai-nilai karakter peserta didik melalui penerapan metode role playing. Jurnal Ekonomi dan Pendidikan, 8(2).

Dewantara, I.P.M., 2012. Identifikasi Faktor Penyebab Kesulitan Belajar Keterampilan Berbicara Siswa Kelas VIIE SMPN 5 Negara dan Strategi Guru untuk Mengatasinya. Jurnal Pendidikan dan Pembelajaran Bahasa Indonesia, 1(2).

Hidayat, R. and Setiawan, T., 2015. Interferensi Bahasa Jawa Ke Dalam Bahasa Indonesia Pada Keterampilan Berbicara Siswa Negeri 1 Pleret, Bantul. LingTera, 2(2), pp.156168.

Kusmintayu, N., Suwandi, S. and Anindyarini, A., 2012. Penerapan metode mind mapping untuk meningkatkan keterampilan berbicara pada siswa sekolah menengah pertama. BASASTRA, 1(1), pp.120-129.

Firmansyah, M.B., 2018. Model Pembelajaran Diskusi Berbasis Perilaku Berliterasi Untuk Keterampilan Berbicara. Jurnal IImiah Edukasi \& Sosial, 8(2), pp.119-125.

Pranowo, D.J., 2013. Implementasi Pendidikan Karakter Kepedulian dan Kerja Sama pada Mata Kuliah Keterampilan Berbicara Bahasa Prancis dengan Metode Bermain Peran. Jurnal Pendidikan Karakter, 2(2).

Rofi"udin, Ahmad, Darmiyati Zuhdi. 2001/2002. Pendidikan Bahasa dan Sastra Indonesia di Kelas Tinggi. Malang: Depdikbud Dirjen Dikti PPTK.

Saddhono, Kundaru dan St. Y. Slamet. 2014. Pembelajaran Keterampilan Berbahasa Indonesia: Teori dan Aplikasi. Yogyakarta: Graha IImu. 
Sari, L.I., Satrijono, H. and Sihono, S., 2015. Penerapan Model Pembelajaran Berbasis Proyek (Project Based Learning) untuk Meningkatkan Hasil Belajar Keterampilan Berbicara Siswa Kelas VA SDN Ajung 03. Jurnal Edukasi, 2(1), pp.11-14.

Siska, Y., 2011. Penerapan metode bermain peran (role playing) dalam meningkatkan keterampilan sosial dan keterampilan berbicara anak usia dini. Jurnal Edukasi. UPI. Edisi Khusus, 2.

Sunarsih, S., 2012. Pembelajaran keterampilan berbicara model kooperatif teknik mencari pasangan dan teknik kancing gemerincing pada siswa introver dan ekstrover di SMP. Seloka: Jurnal Pendidikan Bahasa dan Sastra Indonesia, 1(1).

Sunarto. 2012. Penerapan Metode Bermain Peran untuk Meningkatkan Kemampuan Berbicara Siswa. http://digilid.uns.ac.id. Diakses tanggal 2 Januari 2019.

Suwandewi, Ni M.A. 2013. Peningkatan Berbicara Sor Singgih Bahasa Bali dalam Membangun Karakter Siswa melalui Metode Bermain Peran. http://mafiadoc.com. Diakses tanggal 9 Januari 2019.

Wendra, I Wayan. 2013. Keterampilan Berbicara. Singaraja: Universitas Pendidikan Ganesha.

Wiastra, I N. Gd., dkk. 2013. Penerapan Metode Bermain Peran Untuk Meningkatkan Kemampuan Berbicara Siswa Kelas Ix.3 SMP Negeri 2 Denpasar Tahun 2012/2013. http://media.neliti.com. Diakses tanggal 8 Januari 2019

Widianti, I.A.K.S., Suarni, N.K., Asril, N.M., Psi, S. and Psi, M., 2015. Penerapan metode bercerita dengan media gambar untuk meningkatkan keterampilan berbicara pada anak. Jurnal Pendidikan Anak Usia Dini Undiksha, 3(1).. 